\title{
Is climate change a concern for the ownership of game within fenced wildlife areas?
}

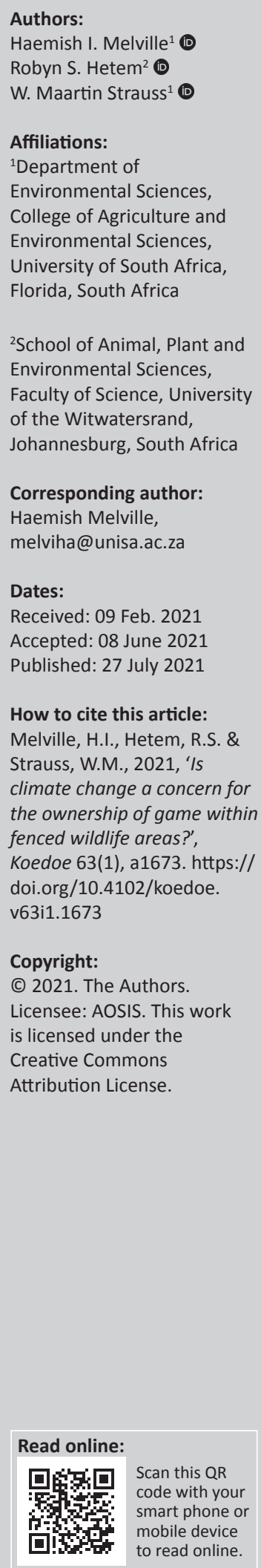

\section{Introduction}

The Game Theft Act 105 of 1991 (hereafter the Game Theft Act) stipulates that ownership of wild animals on a property is vested in the landowner, provided that the landowner has taken steps to prevent the wild animals from escaping. Furthermore, should such wild animals escape, the landowner retains ownership and has the right to recapture these animals, even if the animals escaped onto land owned by someone else (Blackmore 2020). In a recent article entitled 'Climate Change and the Ownership of Game: A concern for fenced wildlife areas', published in Koedoe, Blackmore (2020) suggested that South African legislation relating to game ownership (specifically the clauses within the Game Theft Act that relate to the retention of ownership rights in relation to escaped animals) may require revision under future climate change scenarios. Blackmore (2020) argued that in response to changing climates, wild animals will increasingly escape from fenced wildlife areas (e.g. reserves and game ranches) to seek more favourable habitats, which may result in loss of ownership and reduced economic integrity of the South African wildlife industry. We argue that wildlife enterprises with a commercial focus, which potentially face the greatest risk of reduced economic integrity should their wild animals escape, potentially have access to mitigation options such as the provisioning of food and water resources to retain high value species. Conversely, wildlife enterprises with a conservation focus may benefit from increased connectivity of wildlife areas, which may result in species diversification that would attract more game viewers. Whilst we agree that the Game Theft Act may need revision, we argue that the specific local circumstances, that we outline below, should be taken into account and that additional research and monitoring would be required to inform any proposed revisions.

For the purposes of this narrative, we will confine our frame of reference to larger species of wild animals that may best be described as charismatic megafauna. These include large $(\geq 10 \mathrm{~kg})$ mammals, both carnivores and herbivores, that are typically the focus of South African commercial wildlife enterprises. Wildlife enterprises refer to all wildlife related businesses that involve the containment of wild animals and include national parks as well as small private game reserves.

In South Africa, ecosystem processes are often rigorously managed on both commercial and conservation based wildlife enterprises, for example, animal populations may be subject to control and/or vegetation may be manipulated through controlled burns. Managing animal numbers and the availability of resources (natural or provisioned water and forage) may buffer the adverse effects of increased temperatures and alleviate the pressure for animals to track their moving bioclimatic envelope with changing climates. However, animals might escape from a wildlife enterprise for a variety of reasons, not necessarily linked to climate change. Should new legislation be considered in relation to wildlife ownership in the face of climate change, we would need a better understanding of the drivers underlying animal escapes from wildlife enterprises. We suggest that even if the lower level of evidence, fraction of attributable risk (Pfrommer et al. 2019), were the qualification for the contention that animals were lost or escaped because of climate change, it would be difficult, if not impossible, to prove.

\section{The wildlife industry in South Africa}

Wildlife management is the management of wild animals and their habitats with specific economic, ecological and conservation goals in mind. The wildlife industry in South Africa is unique insofar as it is one of the few countries where wildlife ownership is vested in a landowner, provided the landowner has taken the necessary precautions to establish ownership rights by enclosing the periphery of their property (Blackmore 2020). Most wildlife enterprises, whether 
national, provincial or private, are enclosed by some form of game fence or barrier (natural or manmade) (Hayward \& Somers 2012). Therefore, in the South African context, all wildlife enterprises may be viewed as islands of habitat within a broader land use matrix.

The wildlife industry in South Africa comprises a variety of animal management approaches (modified from Taylor, Lindsey \& Davies-Mostert 2016), which are not necessarily mutually exclusive. These are summarised as:

- ecotourism enterprises

- intensive wildlife production enterprises that include both captive breeding of high value and common species and the intensive breeding of colour morphs of various game species

- trophy hunting enterprises focus on the production of high value individual animals of a variety of species which are offered as trophies (outstanding exemplar individuals) for organised hunting expeditions

- biltong (dried cured meat) hunting and venison production enterprises typically produce regional species for the local recreational hunting fraternity and a growing venison market.

Generally, these management approaches can be divided into those with a conservation focus (e.g. ecotourism) or those with a commercial focus (e.g. intensive wildlife production and hunting) (Taylor et al. 2016). However, it is not unusual for a wildlife enterprise with a commercial focus to incorporate more than one of the above management approaches to generate income. The profitability of intensively managed production systems hinges on the ability of landowners to exert ownership rights over wild animals (Koelble 2011). Consequently, the Game Theft Act is intended to 'protect the interests of the commercial industry' (Blackmore 2020).

The fundamentally different objectives of the various wildlife enterprises may require unique approaches in terms of both management and legislation. A recent amendment to the Animal Improvement Act includes 24 indigenous mammals as landrace breeds (Somers et al. 2020). Arguably, some commercial wildlife enterprises should be reclassified as agricultural because conserving biodiversity is not the priority. The motivation of conserving profitability rather than biodiversity is evident. Few wildlife enterprises manage their land with the objective of conserving habitat for common species (Wade 2020). We emphasise that, from an ecological perspective, all species are valuable and contribute functionally to the ecosystems in which they occur. Therefore, incentivising biodiversity conservation on commercial wildlife enterprises may be worth formalising.

Even if few wildlife enterprises prioritise conservation, one cannot overlook the potential conservation value of large tracts of land dedicated to wildlife production. For example, there may be substantial benefits to species, and natural guilds or assemblages resulting from land under wildlife production. However, management practices purely in pursuit of commercial gain may result in long-term, potentially permanent, alteration of ecosystem function (Holmes et al. 2020).

Despite a large portion of the South African landscape (16.8\%) being under wildlife production (Taylor et al. 2016), much of the land is not in a pristine ecological state and has recently been converted from stock farming. Furthermore, it typically comprises relatively small (median size: 2100 ha), fenced parcels (Taylor et al. 2016) situated in a diverse matrix of land uses, including mining, subsistence and intensive stock and crop production, forestry, rural habitation and urban development (Spierenberg \& Brooks 2014). Hence, the expansion of existing wildlife enterprises and the development of wildlife corridors to facilitate dispersal may not be practicable on a large scale and there may not be much opportunity for individual animals to move.

\section{Climate change and range shifts}

Climate change undoubtedly influences many of the species to which Blackmore (2020) referred. In open systems, mobile animals shift their distribution both polewards latitudinally and upwards altitudinally to track suitable bioclimatic envelopes (Parmesan \& Yohe 2003). However, the geographic pattern of these range shifts may vary and are unlikely to be consistent between species that differ in their thermal tolerance and capacity to persist, which may in turn modify ecosystem structure and function (Walther 2010). Indeed, these indirect effects of climate change may be more pervasive than the direct effects thereof. In short, we need more information on acclimatisation capacity on a variety of species before we can accurately predict how ecosystems may change. The charismatic megafauna on which the wildlife industry depends may be particularly vulnerable to future climate change because of their long generation times and limited capacity to adapt genetically (Hetem et al. 2014). Hence, the future profitability of the game ranching sector is under threat, but it is unclear how a change in the Game Theft Act could ameliorate such challenges.

Within the southern African context, the projected increases in temperature may be exacerbated by a reduction in water availability as a result of increased frequency and severity of droughts, reduced precipitation, increased evapotranspiration and increased water usage as the human population grows (Engelbrecht et al. 2015). Many animals depend on water to dissipate excess heat loads. Reliance on water will likely increase as ambient temperatures increase, consequently the management and availability of free water will influence where, and in what densities, large mammals are able to persist (Fuller et al. 2021). With costs of water provisioning likely to increase, water provisioning may not be a sustainable mitigation 
option and the threshold at which costs outweigh benefits are likely to differ depending on the management model of the wildlife enterprise in question. For conservation enterprises, water management should aim to maintain landscape heterogeneity without disadvantaging waterindependent species (Gaylard, Owen-Smith, \& Redfern 2003) or reducing resilience of water-dependent species (Selebatso et al. 2018). Wildlife enterprises that focus on the production of high value game species may be prepared to invest heavily in resource provisioning negating the need for animals to shift their ranges (Mwakiwa et al. 2013).

\section{Potential options to mitigating the impact of climate change}

Where expansion of wildlife enterprises is feasible, the likely buy-in from landowners may depend on whether the landowners maintain a conservation or commercial focus. Whilst the removal of fences to create corridors or expand wildlife areas may reduce 'economic integrity' of the wildlife production industry that relies on ownership of wildlife for profit (Blackmore 2020), larger wildlife areas that expand suitable habitat for the 'big five' and other wide-ranging species (e.g. African wild dogs, Lycaon pictus) may enhance tourism attractiveness and improve profitability of ecotourism. Indeed, experienced wildlife viewers and local tourists show an increased interest in returning to protected areas that offer opportunities to view rarer species, such as wild dogs (Lindsey et al. 2007).

Whilst we support the suggestion that wildlife enterprises expand their properties to try to accommodate the likely movement of animals because of climate change, we appreciate that it may not always be practical given the amount of additional land likely required to try and ameliorate shifts in the current spatial distribution of megafauna. A more feasible approach, which has already been used to great effect, would be the amalgamation of contiguous wildlife enterprises to allow larger patches of continuous habitat for wild animals. The development of templates for the successful negotiation of ownership rights to overcome challenges associated with varying economic models of component wildlife production strategies will have a direct bearing on the feasibility of this approach. An example of an approach that might inform the development relationships between alternative wildlife management strategies, to the benefit of conservation, is that between the Associated Private Nature Reserves (APNR) and the Kruger National Park.

Contrary to the assertion by Blackmore (2020), the use of corridors need not automatically result in wild animals reverting to their res nulius status. A preventative measure would be for the corridors themselves to be fenced, which would maintain the 'sufficiently enclosed' status of wildlife as is required by the Game Theft Act. Whilst the successful establishment and maintenance of corridors between wildlife areas may be challenging, where practical, corridors in combination with the amalgamation of individual wildlife enterprises may still be the most feasible way to allow for the movement of wild animals in search of resources or more suitable climates.

\section{Conclusion}

Whilst both the economic and ecological underpinnings of wildlife management have advanced substantially within the past four decades, legislation that pertains to the ownership and management of wild animals has largely remained unchanged. As our social, economic and ecological contexts change, it will be necessary for legislation to remain relevant. We support the notion that legislation in relation to the management of wildlife in South Africa, such as the Game Theft Act, should be subject to review. However, this should not simply be justified in the light of a perceived response to climate change but should take the local circumstances and practicalities into consideration.

\section{Acknowledgements Competing interests}

The authors declare that they have no financial or personal relationships that may have inappropriately influenced them in writing this article.

\section{Authors' contributions}

Haemish Melville was responsible for the initiation and conceptualisation of the manuscript and compiling the first draft document. Dr Hetem and Dr Strauss, being experts in the field of mammalian response to climate change, advised and added to the narrative in relation to the specifics that relate to climate change. They also contributed substantively to editing the initial document for submission and contributed by assisting in addressing the reviewers' comments.

\section{Ethical considerations}

This article followed all ethical standards for research without direct contact with human or animal subjects.

\section{Funding information}

This research received no specific grant from any funding agency in the public, commercial or not-for-profit sectors.

\section{Data availability}

Data sharing is not applicable to this article as no new data were used in this scientific letter.

\section{Disclaimer}

The views expressed in this scientific letter are those of the contributing authors and are not necessarily a reflection of any official policy or the stance of the agencies or institutions to which the authors are affiliated. 


\section{References}

Blackmore, A.C., 2020, 'Climate change and the ownership of game: A concern for fenced wildlife areas', Koedoe 62(1), a1594. https://doi.org/10.4102/koedoe.v62i1.1594

Engelbrecht, F., Adegoke, J., Bopape, M.-J., Naidoo, M., Garland, R., Thatcher, M. et al., 2015, 'Projections of rapidly rising surface temperatures over Africa under low mitigation', Environmental Research Letters 10(8), 085004. https://doi. org/10.1088/1748-9326/10/8/085004

Fuller, A., Mitchell, D., Maloney, S.K., Hetem, R.S., Fonseca, V.F.C., Meyer, L.C.R. et al 2021 , 'How dryland mammals will respond to climate change: The effects of body
size, heat load and a lack of food and water', Journal of Experimental Biology 224(1), jeb238113. https://doi.org/10.1242/jeb.238113

Gaylard, A., Owen-Smith, N. \& Redfern, J.V., 2003, 'Surface water availability: Implications for heterogeneity and ecosystem processes', in J.T. Du Toit, K.H.
Rogers \& H.C. Biggs (eds.), The Kruger experience: Ecology and management of savanna heterogeniety, pp. 171-188, Island Press, Washington, DC.

Hayward, M.W. \& Somers, M.J., 2012, 'An introduction to fencing for conservation', in M.J. Somers \& M.W. Hayward (eds.), Fencing for conservation, pp. 1-6, Springer, New York, NY.

Hetem, R.S., Fuller, A., Maloney, S.K. \& Mitchell, D., 2014, 'Responses of large mammals to climate change', Temperature 1(2), 115-127. https://doi.org/10.4161/temp.29651

Holmes, P.M., Esler, K.J., Gaertner, M., Geerts, S., Hall, S.A., Nsikani, M.M. et al., 2020 'Chapter 23: Biological invasions and ecological restoration in South Africa', in: B. Van Wilgen, J. Measey, D. Richardson, J. Wilson \& T. Zengeya (eds.), Biological invasions in South Africa. Invading nature - Springer series in invasion ecology, vo 14 , pp. 665-700, Springer, Cham.

Koelble, T.A., 2011, 'Ecology, economy and empowerment: Ecotourism and the game lodge industry in South Africa', Business and Politics 13(1), 1-24. https://doi. org/10.2202/1469-3569.1333

Lindsey, P.A., Alexander, R., Mills, M.G.L., Romañach, S. \& Woodroffe, R., 2007 'Wildlife viewing preferences of visitors to protected areas in South Africa: Implications for the role of ecotourism in conservation', Journal of Ecotourism 6(1), 19-33. https://doi.org/10.2167/joe133.0
Mwakiwa, E., De Boer, W.F., Hearne, J.W., Slotow, R., Van Langeveld, F., Peel, M. et al., 2013, 'Optimization of wildlife management in a large game reserve through waterpoints manipulation: A bio-economic analysis', Journal of Environmental waterpoints manipulation: A bio-economic analysis', Journal of Environmental
Management 114(2013), 352-361. https://doi.org/10.1016/j.jenvman. Management

Parmesan, C. \& Yohe, G., 2003, 'A globally coherent fingerprint of climate change impacts across natural systems', Nature 421(6918), 37-42. https://doi. org/10.1038/nature01286

Pfrommer, T, Goeschl, T, Proelss, A, Carrier, M., Lenhard, J, Martin, H et al., 2019 'Establishing causation in climate litigation: Admissibility and reliability', Climatic Change 152, 67-84. https://doi.org/10.1007/s10584-018-2362-4

Selebatso, M. Bennitt, E., Maude, G. \& Fynn, R.W., 2018, 'Water provision alters wildebeest adaptive habitat selection and resilience in the Central Kalahari', African Journal of Ecology 56(2), 225-234. https://doi.org/10.1111/ aje.12439

Somers, M.J., Walters, M., Measey, J., Strauss, W.M., Turner, A.A., Venter, J.A. et al, 2020 , 'The implications of the reclassification of South African wildlife species as farm animals', South African Journal of Science 116(1-2), 1-2. https://doi. org/10.17159/sajs.2020/7724

Spierenberg, M. \& Brooks, S., 2014, 'Private game farming and its social consequences in post-Apartheid South Africa: Contestations over wildlife, property, and agrarian futures', Journal of Contemporary African Studies 32(2), 151-172. https://doi.org/10.1080/09637494.2014.937164

Taylor, W.A., Lindsey, P.A. \& Davies-Mostert, H., 2016, An assessment of the economic, social and commercial value of the wildlife ranching industry and its potential to support the green economy in South Africa, Endangered Wildlife Trust, Johannesburg.

Wade, J., 2020, 'Application of harm reduction thinking to the conservation of uncharismatic species', in C. Stephen (ed.), Animals, health and society, pp. 271-278, CRC Press, London.

Walther, G.R., 2010, 'Community and ecosystem responses to recent climate change', Philosophical Transactions of the Royal Society B: Biological Sciences 365(1549), 2019-2024. https://doi.org/10.1098/rstb.2010.0021 